\title{
Teleomorph Formation of Phaeoacremonium aleophilum, Cause of Esca and Grapevine Decline in California
}

\author{
S. Rooney-Latham, A. Eskalen, and W. D. Gubler, Department of Plant Pathology, University of California, Davis, \\ One Shields Ave, 376 Hutchison Hall, Davis 95616
}

\begin{abstract}
Rooney-Latham, S., Eskalen, A., and Gubler, W. D. 2005. Teleomorph formation of Phaeoacremonium aleophilum, cause of esca and grapevine decline in California. Plant Dis. 89:177-184.

Phaeoacremonium is a recently described genus of the hyphomycetes and includes species associated with grapevine (Vitis vinifera) declines worldwide. Spores of Phaeoacremonium spp. have been trapped in infested vineyards, but neither asexual nor sexual fruiting structures have been observed in the field. Mating studies were carried out to determine if California P. aleophilum isolates are capable of forming a teleomorph in vitro. Sterilized grapevine shavings were placed on the surface of water agar plates with pairs of different California isolates of $P$. aleophilum, an isolate from the holotype of P. aleophilum, plus other related Phaeoacremonium spp. After approximately 28 to 35 days, perithecia were seen forming on wood chips and agar of many pairings. Upon maturation, fertile perithecia had gelatinous droplets of ascospores oozing from their ostioles. Successful crosses, resulting in mature perithecia, corresponded to a heterothallic mating type system. When $F_{1}$ progeny were backcrossed with their parents, heterothallism was confirmed. Molecular analyses of the internal transcribed spacer (ITS) region of the nuclear ribosomal DNA from ascospore progeny and perithecia confirmed that these perithecia were the teleomorph of $P$. aleophilum, Togninia minima. Furthermore, 4 months after moist incubating grapevine pieces from naturally infected vineyards, mature perithecia of $T$. minima could be seen forming on the xylem and pith tissues, suggesting both mating types occur on the same vine.
\end{abstract}

Additional keywords: Calosphaeriales, Petri disease

Vine decline, or Petri disease, is a significant and well known, although only recently discovered, disease of young grapevines (Vitis vinifera) (38). Although the symptoms on younger vines differ, decline of older vines, also called esca, apoplexy, black measles, and slowdieback, is caused by the same group of fungal pathogens. The main pathogens have been identified as Phaeomoniella chlamydospora Crous \& Gams (6) and numerous species of Phaeoacremonium $(7,8,19)$. Diseases in both young and old grapevines have been documented in all major viticultural regions throughout the world, including South Africa (17), France (24,25), Australia (30), Austria (33), Italy (29), Portugal $(5,32)$, Argentina (18), and California (37-39).

The occurrence of this disease in California vineyards is widespread. Phaeoacremonium spp. and Phaeomoniella chlamydospora have been isolated from grapevines in all major production regions of California (37-39). Symptoms of grapevine decline vary with age of the host

Corresponding author: S. Rooney-Latham

E-mail: snrooney@ucdavis.edu

Accepted for publication 9 September 2004.

DOI: 10.1094/PD-89-0177

(C) 2005 The American Phytopathological Society and from one season to the next, but can include stunting, shortened internodes, foliar reddening in red varieties, foliar chlorosis in white varieties, shot clusters, spotting and raisining of berries, reduction in root mass, water stress, vascular discoloration, and death $(38,39)$. The disease was first documented in 1912 in a vineyard in Sicily, Italy, that had been replanted with American hybrid rootstocks after an invasion of phylloxera (31). Disease incidence in California also coincided with the replanting of new rootstocks after the infestation of the AXR\#1 rootstock by phylloxera (38). AXR\#1 has now been replaced by other rootstocks after being used almost exclusively in California for 20 years (38).

Large economic losses resulting from this disease have been reported throughout California, especially in areas where massive replants have occurred (38). Hasty vineyard removal, followed by rapid replanting before the problem has been fully assessed, has resulted in significant losses. It is speculated that these fungi, in combination with other stresses on the vines, may cause many of the problems seen in younger vines $(16,38)$. It appears that these fungi are well-adapted endophytes, capable of living asymptomatically inside vines, but have the ability to become severe pathogens as a result of poor cultural practices (38). Such stresses may result from poor irrigation management, premature fruiting, improper planting practices, as well as soils and sites unsuitable for the selected rootstock and/or scion varieties. Recent work by Eskalen et al. (14) has demonstrated that there are differences in susceptibility among rootstocks to these fungi. Although no varieties were shown to be resistant, many rootstocks were shown to be more tolerant than others. Interestingly, their work showed that the most tolerant rootstock variety for both Phaeomoniella chlamydospora and Phaeoacremonium spp. was AXR\#1.

The genus Phaeoacremonium was originally described in 1996 by Crous et al. (7) and accommodates species associated with diseases of both woody plants and humans. Most published research, however, has concentrated on Phaeoacremonium pathogens associated with grapevines, specifically $P$. aleophilum, the most commonly isolated and studied species $(8,19)$. The five other species originally assigned to this genus include $P$. angustius, $P$. inflatipes, $P$. rubrigenum, $P$. parasiticum, and $P$. chlamydosporum (7). Since classification into Phaeoacremonium, $P$. chlamydosporum has been moved into another new genus and renamed Phaeomoniella chlamydospora (6). Recent additions to the Phaeoacremonium genus include P. mortoniae Groenwald et al. (19) and $P$. viticola DuPont et al. (8).

When Phaeoacremonium was originally classified in the Hyphomycetes, no sexual stage for any species in the genus had been identified, nor had any asexual fruiting bodies been observed in the field or in vitro (7). However, spore production of Phaeoacremonium spp. under field conditions is suggested by recovery of propagules from air, soil, and standing water in vineyards $(13,24,34,35)$. Eskalen and Gubler (13) reported that aerial propagules of Phaeoacremonium spp. were present in infected vineyards in multiple counties throughout the state of California. In addition, Eskalen and Gubler (13) and Eskalen et al. (15) correlated many trapping events with rainfall and concluded that these pathogens are dispersed as airborne inoculums during rainfall events Rooney (34) and Rooney et al. (35) showed that propagules of Phaeoacremonium spp. are present in vineyard soil as well as in standing water underneath irrigation drip emitters. No propagules were found in the water as it was being emitted from the irrigation tube, suggesting inoculum is at ground level. 
Phaeomoniella chlamydospora produces pycnidia on cordons and spurs of grapevines $(11,12,15)$, which may serve as the source of the trapped spores. However, fruiting bodies of Phaeoacremonium spp. have not been reported on grapevines in nature, and it is unclear where airborne inocula of these fungi are produced and whether this inoculum is important in the disease cycle. Rooney (34) and Rooney et al. (36) were the first to show that isolates of Phaeoacremonium spp. were capable of forming perithecia in vitro. Mostert et al. (28) later confirmed teleomorph associations among South African isolates of $P$. aleophilum and identified the teleomorph as Togninia minima, a member of the Calosphaeriales.

Recombination in sexually reproducing fungi can greatly alter an organism's genetic structure, often making it more adaptable to changing environments, providing an advantage over asexual fungi (4). Furthermore, sexual reproduction can produce fruiting structures capable of withstanding extreme conditions and spores capable of being dispersed long distances via air, rain, and insects. Therefore, determining the mode and occurrence of the sexual stage of a fungal pathogen can be very important in understanding disease epidemiology. Studies of fungal mating behavior have proved to be important for Magnaporthe, Uncinula, and Fusarium $(23,26,27,43)$.

The purpose of this research was to determine whether California isolates of $P$. aleophilum are in fact the anamorph of Togninia minima, to optimize a mating system for $P$. aleophilum, and to determine whether the teleomorph occurs in California vineyards.

\section{MATERIALS AND METHODS}

Selection and storage of isolates. Isolates of $P$. aleophilum used in this study were primarily from grapevines in California, but also included one isolate from France and one from South Africa (Table 1). To obtain single-spore colonies, isolates were grown on either potato dextrose agar or malt extract agar (Difco Laboratories, Detroit, MI; BD Microbiology Systems, Franklin Lakes, NJ) amended with $0.01 \%$ tetracycline hydrochloride (PDA-tet and MEA-tet, respectively). Isolates were transferred to MEA-tet overlaid with sterile Whatman no. 1 filter papers (Whatman International Ltd., Maidstone, England). Once fully colonized, filter papers were dried and stored in sterile vials at $0^{\circ} \mathrm{C}$. All cultures used in this study are maintained in the Phaeoacremonium spp. collection in the department of plant pathology at the University of California, Davis.

Mating tests. $P$. aleophilum isolates (Table 1) were removed from storage and subcultured on fresh plates of PDA-tet. After 10 days of incubation at $23^{\circ} \mathrm{C}$ $\left(+/-3^{\circ} \mathrm{C}\right)$, a $3-\mathrm{mm}$-diameter agar plug was taken from the growing margin of the colony. Agar plugs from each of two different isolates were placed on opposite sides of a 9-cm-diameter petri dish containing 1.5\% (wt/vol) water agar. Because mating types were unknown, isolates were paired in all possible combinations, including selfpairings. Each pair of isolates was replicated three times. Plates were sealed with Parafilm and incubated at $23^{\circ} \mathrm{C}\left(+/-3^{\circ} \mathrm{C}\right)$ with a 12-h photoperiod provided by a single $40 \mathrm{~W}$ fluorescent light.

When hyphae of the paired isolates merged at the center of the plate, usually within 2 weeks, sterilized grapevine xylem tissue of rootstock cultivar Teleki 5C was placed on the merged hyphae. The plates were maintained under the conditions described above and examined microscopically at weekly intervals for the presence of fruiting structures. A final observation

Table 1. Phaeoacremonium isolates selected for pairing experiments to assess mating types and interspecies fertility

\begin{tabular}{|c|c|c|c|}
\hline Isolate & Species & Host and location & $\begin{array}{l}\text { ITS GenBank } \\
\text { accession no. }\end{array}$ \\
\hline 5 & P. aleophilum & Vitis vinifera $\mathrm{USA}$ & \\
\hline 40 & P. aleophilum & V. vinifera $\mathrm{El}$ Dorado Co., CA, USA & \\
\hline 52 & P. aleophilum & $V$. vinifera South Africa & \\
\hline 67 & P. aleophilum & V. vinifera San Joaquin Co., CA, USA & AY644478 \\
\hline 74 & P. aleophilum & $V$. vinifera Sonoma Co., CA, USA & \\
\hline 76 & $P$. aleophilum & V. vinifera Riverside Co., CA, USA & \\
\hline 80 & P. aleophilum & V. vinifera Napa Co., CA, USA & AY644479 \\
\hline 83 & P. aleophilum & V. vinifera San Joaquin Co., CA, USA & \\
\hline 85 & P. aleophilum & V. vinifera Mendocino Co., CA, USA & \\
\hline 100 & P. aleophilum & V. vinifera Sonoma Co., CA, USA & \\
\hline 102 & P. aleophilum & V. vinifera Contra Costa Co., CA, USA & \\
\hline $\mathrm{Fr}$ & P. aleophilum & $V$. vinifera France & \\
\hline$F_{1}$ Prog. $(67 \times 80)$ & P. aleophilum & $V$. vinifera USA & AY644480 \\
\hline$F_{1}$ Prog. $(67 \times 85)$ & P. aleophilum & $V$. vinifera $\mathrm{USA}$ & \\
\hline CBS $246.91 * \mathrm{a}$ & P. aleophilum & $V$. vinifera Yugoslavia & AF017651 \\
\hline CBS 631.94 & P. aleophilum & $V$. vinifera Italy & AF266647 \\
\hline CBS $249.95 *$ & $P$. angustius & V. vinifera Monterey Co., CA, USA & AF197974 \\
\hline CBS $101738 *$ & $P$. viticola & V. vinifera France & AF118137 \\
\hline CBS 166.75 & P. inflatipes & Dead Nectandra sp. Costa Rica & U31843 \\
\hline CBS $101585^{*}$ & P. mortoniae & $V$. vinifera $\mathrm{CA}, \mathrm{USA}$ & AF295328 \\
\hline
\end{tabular}

a * Ex-type culture. of all pairings was made 10 weeks later. If perithecia with mature ascospores were observed on any of the three replicate plates, then that isolate combination was considered fertile. This experiment was conducted twice.

An additional mating experiment was done with our $P$. aleophilum isolates and isolates of Phaeoacremonium spp. obtained from Centraalbureau voor Schimmelcultures (Fungal Biodiversity Center, Utrecht, The Netherlands [CBS]). These isolates included both holotype and nontype isolates of $P$. aleophilum, $P$. inflatipes, $P$. viticola, $P$. angustius, and $P$. mortoniae (Table 1). In addition, 16 single ascospore progeny $\left(\mathrm{F}_{1}\right)$ obtained from the first pairing experiment were crossed back with parental $P$. aleophilum isolates and Phaeoacremonium isolates from CBS to confirm heterothallism. In this experiment, sterile grapevine wood shavings were placed at the center of each plate at the time they were inoculated, and selfpairings were not done. This experiment was conducted twice.

At maturity, perithecia continuously oozed a sticky mass of spores, which accumulated at the ostiole. To obtain $\mathrm{F}_{1}$ single-spore progeny cultures, spore masses were removed from perithecia with a sterile scalpel or needle and serially diluted in sterile water. Serial dilutions and plating allowed recovery of single-ascosporederived colonies. Single ascospores germinated on agar plates within $72 \mathrm{~h}$ and could be best seen on the $10^{-3}$ dilution plates. Eight single-ascospore colonies from each perithecium were subcultured on PDA-tet and stored as described above.

DNA extraction, polymerase chain reaction (PCR) amplification, and sequencing. Single conidial isolates of $P$. aleophilum and Phaeoacremonium species from CBS, as well as a single ascospore isolate from a cross of isolates 67 and 80, were grown on MEA for 14 days, and DNA was extracted using PrepMan Ultra Sample Preparation Reagent (Applied Biosystems, Foster City, CA).

Once DNA was obtained, oligonucleotide primers ITS4 and ITS5 (44) were used to amplify and sequence the internal transcribed spacer (ITS) region, including the 5.8S gene. Reactions included the following: $10 \mu \mathrm{l} \mathrm{Ex} \mathrm{Taq}$ buffer, $200 \mathrm{mM}$ dNTPs, $0.5 \mathrm{mM}$ of each primer, and 2.5 units Takara Ex Taq polymerase (Takara Shuzo Co., LTD, Shiga, Japan). Approximately 2 $\mu \mathrm{l}$ of template DNA was added to each reaction tube, with a final reaction volume of $100 \mu \mathrm{l}$. PCR reactions were performed on a Perkin-Elmer Gene Amp PCR System 2400 (Shelton, CT) or an M.J. Research, Inc. PTC-100 System (Waltham, MA). Cycling conditions included an initial denaturation for $4 \mathrm{~min}$ at $94^{\circ} \mathrm{C}$, followed by 35 cycles of denaturation $\left(94^{\circ} \mathrm{C}\right)$ for $60 \mathrm{~s}$, annealing $\left(60^{\circ} \mathrm{C}\right)$ for $60 \mathrm{~s}$, and extension $\left(72^{\circ} \mathrm{C}\right)$ for $90 \mathrm{~s}$. A final extension was per- 
formed at $72^{\circ} \mathrm{C}$ for $10 \mathrm{~min}$. The PCR products were purified using a QIAquick DNA Purification Kit (Qiagen, Hilden, Germany) and quantified using a DyNA Quant 200 fluorometer (Amersham Pharmacia Biotech, Piscataway, NJ). Products were then sequenced at the University of California, Davis, using Applied Biosystems PRISM BigDye Terminators v3.0 Cycle Sequencing Kit with AmpliTaq DNA Polymerase or at the Iowa State University sequencing facility using Applied Biosystems ABI Prism 377 sequencers.

DNA sequence analysis. ITS sequences from California $P$. aleophilum isolates and isolates of Phaeoacremonium spp. obtained from CBS were compared with sequences from GenBank (AY179948 of Phialophora richardsiae Nannfeldt (Conant), AY179930 of Togninia minima Tulasne \& Tulasne (Berlese), AF197974 of Phaeoacremonium angustius, U31843 of $P$. inflatipes, AF017651 and AF266647 of P. aleophilum, AF118137 of P. viticola, and AF295328 of $P$. mortoniae) and aligned using Clustal X Version 1.8 (41). Sequences were further manually aligned using MacClade version 3.07 (Sinauer Associates, Inc., Publishers, Sunderland, MA) and deposited into TreeBASE (Study accession no. S1175, Matrix accession no. M2032). Maximum parsimony heuristic analysis using branch swapping (NNI) and 1,000 bootstrap replications was performed using PauP 4.0b10 (Sinauer Associates). All sequences used in the final phylogenetic tree were deposited into GenBank (Table 1), and the alignment was deposited into TreeBASE.

Temperature study. Descriptions of Phaeoacremonium spp. note that $P$. aleophilum is capable of growing at $35^{\circ} \mathrm{C}$, whereas the morphologically similar $P$. angustius is not (7). Therefore, all of the isolates used in our pairings were grown at $35^{\circ} \mathrm{C}$. Agar plugs $(3 \mathrm{~mm}$ diameter) were removed from the growing margins of 10day-old cultures of all isolates used in the pairings and were placed in the center of PDA-tet plates. Five plates for each isolate were incubated in the dark at $35^{\circ} \mathrm{C}$ for 2 weeks, when colony diameter was recorded. Pigment diffusion on agar can be another means to differentiate Phaeoacremonium species and was also recorded for each of the isolates. This experiment was conducted twice.

Light study. Pairings were also made to determine if perithecium formation required light. A known fertile combination of isolates (CBS 249.95 and 85) was paired on each of 40 plates as previously described. Cultures were incubated at $23^{\circ} \mathrm{C}\left(+/-3^{\circ} \mathrm{C}\right)$ for 2 weeks in the dark before sterile grapevine pieces were placed where mycelial growth of the two isolates merged. Half of the plates were placed at $23^{\circ} \mathrm{C}\left(+/-3^{\circ} \mathrm{C}\right)$ under a $40 \mathrm{~W}$ fluorescent light with a 12-h photoperiod (light re- gime), and the other 20 were placed at the same temperature but were wrapped in two layers of foil to prevent light from reaching the plates (dark regime). Twenty-eight days later, both light and dark regime plates were microscopically observed for the presence of perithecia, and the number of plates with mature perithecia was recorded. At this time, foil was removed from the dark-incubated plates, which were thereafter maintained under the same light regime as the other 20 plates. These plates were examined weekly for the presence of perithecia. This experiment was conducted twice. For each run, the proportion of the total number of plates with perithecia was calculated for each treatment (light or dark regime) and at each time. The proportion of plates for each treatment was treated as a repeated measure and subjected to a repeated measures analysis of variance (ANOVA). Proportion values for the two runs were not statistically different and therefore combined to obtain a total mean for each treatment. Treatment means at each time were then separated by Tukey's test $(P<0.0001)$. All statistical analyses were performed using the SAS statistical package (SAS Institute, Cary, NC).

Vineyard survey. A study by Eskalen et al. (13) showed that aerial spores of $P$. aleophilum were present in vineyards throughout California. Three vineyards in three different counties (Madera, Tulare, and Mendocino) where abundant spores had been trapped were visited three times between June 2003 and February 2004 in search of the sources of these spores. Vines containing spore traps, as well as those in the immediate vicinity, were examined for the presence of fruiting bodies. Various

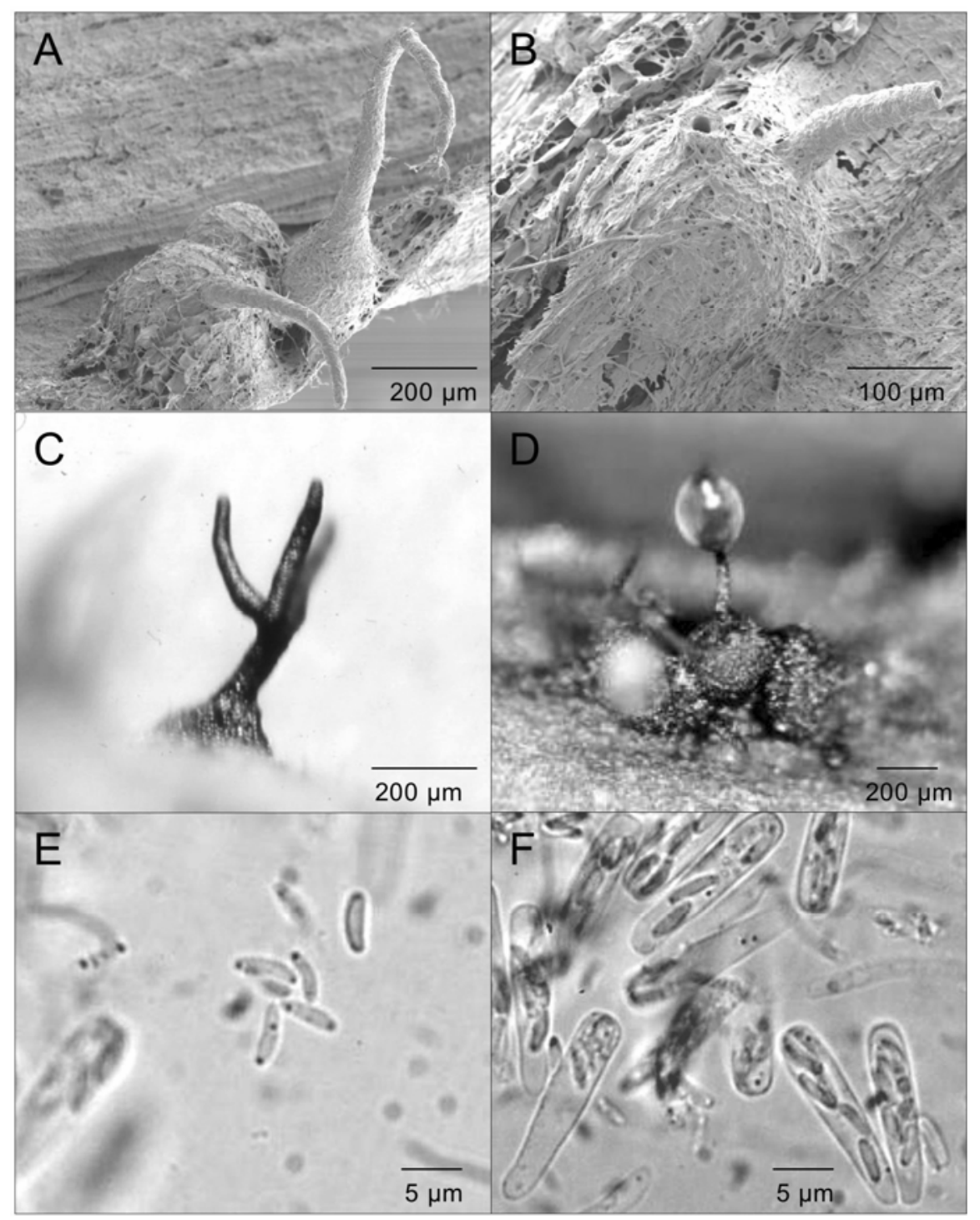

Fig. 1. Teleomorph of Phaeoacremonium aleophilum produced in vitro on grapevine vascular tissue. A, Scanning electron microscope (SEM) photograph showing perithecia on host tissue. B, SEM photograph showing a perithecium with two necks, one of which was broken off at its base. $\mathbf{C}$, Perithecium with a branching neck. D, Mature perithecium (center) with ascospores being exuded out of the ostiole in a gelatinous matrix. E, Allantoid, one-celled, biguttulate ascospores released from asci. F, Squash mount of a perithecium showing septate paraphyses and ascospores inside oblong to clavate asci. 
pieces from these vines, including cordons, spurs, and trunks, were brought to the laboratory from each site for further study. Ten tissue pieces from each vineyard were microscopically examined for perithecia. Another 10 pieces were cut into crosssection pieces and moist incubated on wire racks in plastic crispers containing sterile distilled water. Crispers were placed at $23^{\circ} \mathrm{C}\left(+/-3^{\circ} \mathrm{C}\right)$ with a 12 -h photoperiod provided by a single $40 \mathrm{~W}$ light. Pieces in crispers were examined weekly for any developing fruiting bodies. Suspect fruiting bodies were surface sterilized by briefly dipping in $70 \% \mathrm{EtOH}$, blotting on a paper towel, and plated on PDA-tet. Colonies on PDA-tet were examined after 10 days.

\section{RESULTS}

Mating tests. Approximately 21 days after wood shavings were added to paired cultures of $P$. aleophilum, protoperithecialike structures began to form on wood surfaces and in the agar. After 28 to 35 days, protoperithecia developed into mature perithecia (Fig. 1A). Perithecia were black, globose, superficial to embedded on the substrates (Fig. 1A and B), and formed solitarily or in small groups. Perithecia were also found on the surface of the host tissue. Individual perithecia often formed multiple or branched necks (Fig. 1B and C). Upon maturation, gelatinous masses of ascospores oozed from the ostiole, collected at the tip (Fig. 1D), and slid partially down the neck. Ascospores were hyaline, biguttulate, and ellipsoid to allantoid in shape (Fig. 1E). Dissections of perithecia revealed intact asci (Fig. 1F), which were unitunicate, octosporous, oblong to clavate in shape, and formed in acropetal succession from ascogenous hyphae.

Measurements of 100 perithecia, asci, and ascospores were taken using an ocular micrometer after 35 days, and mean dimensions were calculated. The mean diameter of sampled perithecia was $241 \mu \mathrm{m}$ and ranged from 160 to $350 \mu \mathrm{m}$. The elongated necks had a mean length of $425 \mu \mathrm{m}$ and ranged from 200 to $1,000 \mu \mathrm{m}$ but reached lengths of $1,500 \mu \mathrm{m}$ after 6 months. The asci averaged $15.4 \mu \mathrm{m}$ long by $3.1 \mu \mathrm{m}$ wide, with a range of 11 to 21 $\mu \mathrm{m}$ by 2.5 to $4.0 \mu \mathrm{m}$. Means for the asco-

Table 2. Interfertility among field isolates of Phaeoacremonium aleophilum using all possible pairwise combinations to assess mating types

\begin{tabular}{|c|c|c|c|c|c|c|c|c|c|c|c|c|c|}
\hline Isolate & 5 & 40 & 52 & 76 & 80 & 85 & 102 & 100 & 67 & 74 & 83 & $\mathbf{F r}$ & $\begin{array}{c}\text { Mating } \\
\text { type }^{\mathrm{a}}\end{array}$ \\
\hline 5 & $-/-^{\mathrm{b}}$ & $-1-$ & $-1-$ & $-1-$ & $-1-$ & $-1-$ & $-1-$ & $+/+$ & $+/+$ & $-1+$ & $-1+$ & $-1+$ & B \\
\hline 40 & & $-1-$ & $-1-$ & $-1-$ & $-1-$ & $-1-$ & $-1-$ & $+/+$ & $-1+$ & $-1+$ & $+/+$ & $-1+$ & B \\
\hline 52 & & & $-1-$ & $-1-$ & $-1-$ & $-1-$ & $-1-$ & $-1+$ & $-1+$ & $+/+$ & $-1+$ & $-1+$ & B \\
\hline 76 & & & & $-1-$ & $-1-$ & $-1-$ & $-1-$ & $+/+$ & $-1+$ & $-1+$ & $-1+$ & $-1+$ & B \\
\hline 80 & & & & & $-1-$ & $-1-$ & $-1-$ & $+/+$ & $+/+$ & $+/+$ & $+/+$ & $-1+$ & B \\
\hline 85 & & & & & & $-1-$ & $-1-$ & $+/+$ & $+/+$ & $-1+$ & $-/+$ & $-1-$ & B \\
\hline 102 & & & & & & & $-1-$ & $+/+$ & $-1+$ & -+ & $-1-$ & $+/+$ & B \\
\hline 100 & & & & & & & & $-1-$ & $-1-$ & $-1-$ & $-1-$ & $-1-$ & A \\
\hline 67 & & & & & & & & & $-1-$ & $-1-$ & $-1-$ & $-1-$ & A \\
\hline 74 & & & & & & & & & & $-1-$ & $-1-$ & $-1-$ & A \\
\hline 83 & & & & & & & & & & & $-1-$ & $-1-$ & A \\
\hline $\mathrm{Fr}$ & & & & & & & & & & & & $-1-$ & A \\
\hline
\end{tabular}

a Deduced mating type (A or B).

${ }^{\mathrm{b}}$ Production of perithecia and viable ascospores $(+)$ or no interaction $(-)$ seen in each of two replicate pairings.

Table 3. Interfertility among field isolates of Phaeoacremonium aleophilum, $\mathrm{F}_{1}$ progeny, and other Phaeoacremonium species to assess mating types and interspecies fertility

\begin{tabular}{|c|c|c|c|c|c|c|c|c|c|c|c|}
\hline Isolate & $\begin{array}{c}67 \\
\text { "A" }\end{array}$ & $\begin{array}{l}100 \\
\text { "A" }\end{array}$ & $\begin{array}{c}80 \\
\text { "B", }\end{array}$ & $\begin{array}{c}85 \\
\text { "B" }\end{array}$ & $\begin{array}{c}\text { CBS } \\
246.91\end{array}$ & $\begin{array}{c}\text { CBS } \\
631.94\end{array}$ & $\begin{array}{c}\text { CBS } \\
249.95\end{array}$ & $\begin{array}{c}\text { CBS } \\
166.75\end{array}$ & $\begin{array}{c}\text { CBS } \\
101585\end{array}$ & $\begin{array}{c}\text { CBS } \\
101738\end{array}$ & $\begin{array}{c}\text { Mating } \\
\text { type }^{\mathrm{a}}\end{array}$ \\
\hline $67-80(1)$ & $+/+^{b}$ & $-1+$ & $-1-$ & $-1-$ & $-1-$ & $-1-$ & $+/+$ & $-1-$ & $-1-$ & $-1-$ & B \\
\hline $67-80(2)$ & $+/+$ & $-1+$ & $-1-$ & $-1-$ & $-1-$ & $-1-$ & $+/+$ & $-1-$ & $-1-$ & $-1-$ & B \\
\hline $67-80(3)$ & $+/+$ & $+/+$ & $-/+$ & $-/+$ & $-1-$ & $-1-$ & $+/+$ & $-1-$ & $-1-$ & $-1-$ & $\mathrm{B}$ ? \\
\hline $67-80(4)$ & $+/+$ & $+/-$ & $-1-$ & $-1-$ & $-1-$ & $-1-$ & $+/+$ & $-1-$ & $-1-$ & $-1-$ & B \\
\hline $67-80(5)$ & $-1-$ & $-1-$ & $+/+$ & $+1-$ & $\mathrm{NT}^{\mathrm{c}}$ & NT & $\mathrm{NT}$ & NT & NT & NT & A \\
\hline $67-80(6)$ & $-1-$ & $-1-$ & $+/+$ & $-/+$ & NT & NT & NT & NT & NT & NT & $\mathrm{A}$ \\
\hline $67-80(7)$ & $-1-$ & $-1-$ & $-/+$ & $-/+$ & NT & NT & NT & NT & NT & NT & A \\
\hline $67-80(8)$ & $+1-$ & $-1-$ & $-1-$ & $-1-$ & NT & NT & NT & NT & NT & NT & B \\
\hline $67-85$ (1) & $+/+$ & $-1-$ & $-1-$ & $-1-$ & $+/-$ & $-1-$ & $+/+$ & $-1-$ & $-1-$ & $-1-$ & B \\
\hline $67-85(3)$ & $+/+$ & $-1+$ & $-1-$ & $-1-$ & $-1-$ & $-1-$ & $+/+$ & $-1-$ & $-1-$ & $-1-$ & B \\
\hline $67-85(4)$ & $+/+$ & $+/+$ & $-1-$ & $-1-$ & $-1-$ & $-1-$ & $+/+$ & $-1-$ & $-1-$ & $-1-$ & B \\
\hline $67-85(5)$ & $-/+$ & $-1-$ & $+/+$ & $+/+$ & $-1-$ & $-1+$ & $-1-$ & $-1-$ & $-1-$ & $-1-$ & A? \\
\hline $67-85(6)$ & $-1-$ & $-1-$ & $+/+$ & $+/+$ & NT & NT & NT & NT & NT & NT & A \\
\hline $67-85(7)$ & $-1-$ & $-1-$ & $+/+$ & $+/+$ & NT & NT & NT & NT & NT & NT & A \\
\hline $67-85(8)$ & $+/+$ & $+/+$ & $-1-$ & $-1-$ & NT & NT & NT & NT & NT & NT & B \\
\hline $67-85(9)$ & $-1-$ & $-1-$ & $+/+$ & $+/+$ & NT & NT & NT & NT & NT & NT & A \\
\hline $\begin{array}{l}\text { CBS } 246.91 \\
\quad(P . \text { aleophilum })\end{array}$ & $-1-$ & $-1-$ & $-1-$ & $+/+$ & $-1-$ & $-1-$ & $-1-$ & $-1-$ & $-1-$ & $-1-$ & A \\
\hline $\begin{array}{l}\text { CBS } 631.94 \\
(P . \text { aleophilum })\end{array}$ & $+/+$ & $-1+$ & $-1-$ & $-1-$ & $-1-$ & $-1-$ & $-1+$ & $-1-$ & $-1-$ & $-1-$ & B \\
\hline $\begin{array}{l}\text { CBS } 249.95 \\
(P . \text { angustius })\end{array}$ & $-1-$ & $-1-$ & $+/+$ & $+/+$ & $-1-$ & $-1+$ & $-1-$ & $-1-$ & $-1-$ & $-1-$ & A \\
\hline $\begin{array}{r}\text { CBS } 101738 \\
(P . \text { viticola })\end{array}$ & $-1-$ & $-1-$ & $-1-$ & $-1-$ & $-1-$ & $-1-$ & $-1-$ & $-1-$ & $-1-$ & $-1-$ & - \\
\hline $\begin{array}{l}\text { CBS } 166.75 \\
(P . \text { inflatipes })\end{array}$ & $-1-$ & $-1-$ & $-1-$ & $-1-$ & $-1-$ & $-1-$ & $-1-$ & $-1-$ & $-1-$ & $-1-$ & - \\
\hline $\begin{array}{l}\text { CBS } 101585 \\
(P . \text { mortoniae })\end{array}$ & $-1-$ & $-1-$ & $-1-$ & $-1-$ & $-1-$ & $-1-$ & $-1-$ & $-1-$ & $-1-$ & $-1-$ & - \\
\hline
\end{tabular}

a Deduced mating type (A, B, or neither, -).

${ }^{\mathrm{b}}$ Production of perithecia and viable ascospores $(+)$ or no interaction $(-)$ seen in each of two replicate pairings.

c NT = pairing not tested. 
spores were $4.3 \mu \mathrm{m}$ long by $1.1 \mu \mathrm{m}$ wide, with a range of 3.5 to $6.0 \mu \mathrm{m}$ by 1.0 to 1.5 $\mu \mathrm{m}$. Ascospores were viable and germinated within 48 to $72 \mathrm{~h}$ on PDA-tet.

Pairing results of field isolates of $P$. aleophilum were consistent with a heterothallic mating type system (Table 2). Five isolates $(42 \%), 100,67,74,83$, and $\mathrm{Fr}$, corresponded to one mating type (designated mating type "A") and only formed perithecia with members of the other mating type (designated mating type "B"), which included seven isolates $(58 \%), 5$, 40, 52, 76, 80, 85, and 102 .

Four isolates, identified as mating type tester strains (67 and 100 as type "A", 80 and 85 as type "B"), were used with backcrosses of single-ascospore $F_{1}$ cultures and confirmed that each of our isolates, as well as the P. aleophilum isolates CBS 246.91 and CBS 631.94, were one of the two mating types (Table 3). In most cases, only crosses between strains of opposite mating type resulted in perithecia and ascospores. Of the 16 progeny tested, six (38\%) were mating type "A" and eight $(50 \%)$ were mating type "B". Two of the tested progeny isolates, 67-80 (3) and 67-85 (5), formed perithecia with both mating types in the second repetition. Pairings with type and nontype isolates of other Phaeoacremonium species (CBS 101738 P. viticola, CBS 166.75 P. inflatipes, and CBS $101585 P$. mortoniae) did not yield fertile perithecia.

DNA sequence analysis. Phylogenetic analysis of the ITS sequences using a heuristic search of branch swapping (NNI) resulted in three equally parsimonious trees. A majority rule consensus tree was obtained before performing a bootstrap analysis using 1,000 replicates. Tree length, consistency index (CI), retention index (RI), and rescaled consistency index (RC) were also calculated and recorded (Fig. 2). Single-spore isolates 67, 80, and a cross of 67 and 80 formed a clade of $100 \%$ bootstrap support with closely related GenBank sequences AF017651 and AF266647 of P. aleophilum, AY179930 of Togninia minima, and our sequence of CBS 249.95 P. angustius. This clade separated from another clade of Phaeoacremonium species containing GenBank accessions $P$. viticola (AF118137), P. mortoniae (AF295328), and P. angustius (AF197974).

Temperature study. In both trials, all of our interfertile isolates were capable of growing at $35^{\circ} \mathrm{C}$, further suggesting that they are $P$. aleophilum (Table 4). The CBS isolates $P$. aleophilum, $P$. angustius, and $P$. inflatipes isolates also all grew at $35^{\circ} \mathrm{C}$. Only $P$. viticola and $P$. mortoniae were unable to grow at $35^{\circ} \mathrm{C}$. Furthermore, all of our interfertile isolates produced a yellow pigment in culture, as did the $P$. aleophilum and $P$. angustius isolates. Cultures of $P$. mortoniae, $P$. viticola, and $P$. inflatipes did not produce a pigment in our study.

Light study. After 28 days, $88 \%$ of the cultures incubated in the light had formed perithecia, whereas only $2.5 \%$ of those incubated in the dark had formed perithecia (Table 5). At this point, the 20 darkincubated plates were transferred to the same light regimen as the 20 lightincubated plates, because it was evident that light was a possible factor for perithecia development. Twenty-one days after being placed under the light regimen (a total incubation period of 49 days), $38 \%$ of the plates initially placed in the dark formed perithecia compared with $100 \%$ of

Phialophora richardsiae CBS 270.33

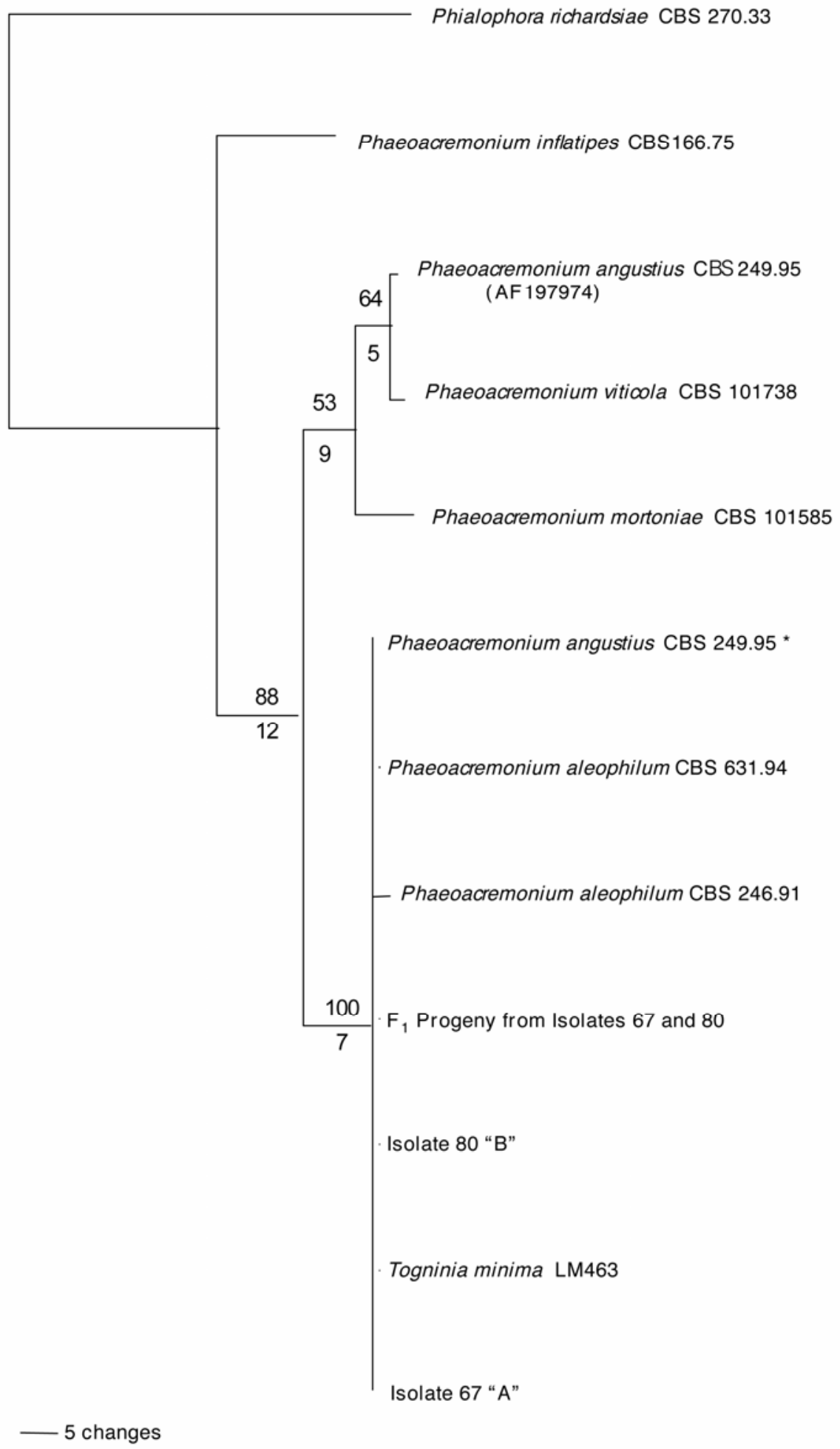

Fig. 2. Majority rule consensus tree of the three most parsimonious trees generated from heuristic searches of the aligned sequences of the DNA region containing ITS1, 5.8S rDNA, and ITS2 (tree length $=146$, consistency index $=0.904$, retention index $=0.754$, rescaled consistency index $=0.682$ ). Phialophora richardsiae (AY179948) was used as an outgroup. Branch lengths (base substitutions) are indicated below branches and bootstrap values above. (* Denotes CBS 249.95 Phaeoacremonium angustius sequence obtained by our study. GenBank accession AF197974 for CBS 249.95 was also used in this study). 
those continuously under the light regime. Thirty-five days after placing the darkregime plates under the light, or at 63 days of total incubation, there was no statistical difference $(P<0.0001)$ between this mean $(88 \%)$ and that of the plates placed under continuous light $(100 \%)$.

Vineyard survey. Mature perithecia were not seen directly on grapevine pieces removed from any of the vineyards. However, after approximately 4 months of moist incubation, mature perithecia, similar to those perithecia produced in previous in vitro mating studies of $P$. aleophilum isolates, could be seen forming on four trunk cross sections from a Vitis vinifera cv. Thompson Seedless grapevine from Tulare County, CA (Fig. 3). Perithecia were most abundant in the area immediately between the pith and older xylem tissue, but were also observed scattered throughout the rest of the xylem tissue, even though the tissue was completely colonized by Fomitoporia spp. Perithecia were identical in size, shape, and color, and formed in the same manner as described in previous mating studies. Perithecia produced copious amounts of viable ascospores that germinated and formed colonies typical of $P$. aleophilum when plated on PDA-tet. Perithecia were not seen on moist incubated wood pieces from the vineyards in Madera and Mendocino counties.

\section{DISCUSSION}

These studies confirmed that California isolates of $P$. aleophilum are capable of mating in a heterothallic type system. Furthermore, field isolates of $P$. aleophilum and $\mathrm{F}_{1}$ progeny of crosses between California isolates were successfully crossed with the type isolate of $P$. aleophilum (CBS 246.91). However, these same isolates also formed perithecia when paired with the type isolate of $P$. angustius (CBS 249.95), leading us to believe either that $P$. angustius (CBS 249.95) is a synonym of $P$. aleophilum or that the culture does not represent the holotype.

Each $P$. aleophilum mating type was associated with isolates from a wide range of geographical and climatic areas. Mating type "B" isolates included those from hot, arid areas such as inland Riverside County in Southern California, as well as from cooler areas such as El Dorado County in the foothills of the California Sierra Nevada. Another isolate, originating from South Africa, was also shown to be inter-

Table 4. Colony growth at $35^{\circ} \mathrm{C}$ and pigment diffusion among selected Phaeoacremonium spp. isolates

\begin{tabular}{lccc}
\hline Isolate & Species & $\begin{array}{c}\text { Pigment } \\
\text { diffusion }\end{array}$ & $\begin{array}{c}\text { Growth } \\
\text { at } \mathbf{3 5}^{\circ} \mathbf{C}\end{array}$ \\
\hline 5 & P. aleophilum & Yes & Yes \\
40 & P. aleophilum & Yes & Yes \\
52 & P. aleophilum & Yes & Yes \\
67 & P. aleophilum & Yes & Yes \\
74 & P. aleophilum & Yes & Yes \\
76 & P. aleophilum & Yes & Yes \\
80 & P. aleophilum & Yes & Yes \\
83 & P. aleophilum & Yes & Yes \\
85 & P. aleophilum & Yes & Yes \\
100 & P. aleophilum & Yes & Yes \\
102 & P. aleophilum & Yes & Yes \\
Fr & P. aleophilum & Yes & Yes \\
F1 Prog. $(67 \times 80)$ & P. aleophilum & Yes & Yes \\
F Prog. $(67 \times 85)$ & P. aleophilum & Yes & Yes \\
CBS 246.91 & P. aleophilum & Yes & Yes \\
CBS 631.94 & P. aleophilum & Yes & Yes \\
CBS 249.95 & P. angustius & Yes & No \\
CBS 101738 & P. viticola & No & Yes \\
CBS 166.75 & P. inflatipes & No & No \\
CBS 101585 & P. mortoniae & No & \\
\hline & & &
\end{tabular}

Table 5. Proportion of plates with mature perithecia that were placed under either an initial light or dark regime

\begin{tabular}{lllllll}
\hline & \multicolumn{7}{c}{ Days } \\
\cline { 2 - 7 } Treatment & $\mathbf{2 8}^{\mathbf{a}}$ & $\mathbf{3 5}$ & $\mathbf{4 2}$ & $\mathbf{4 9}$ & $\mathbf{5 6}$ & $\mathbf{6 3}$ \\
\hline Light regime (1) & 0.80 & 0.95 & 1.00 & 1.00 & 1.00 & 1.00 \\
Light regime (2) & 0.95 & 0.95 & 1.00 & 1.00 & 1.00 & 1.00 \\
Light regime mean & $0.88^{* \mathrm{~b}}$ & $0.95^{*}$ & $1.00^{*}$ & $1.00^{*}$ & $1.00^{*}$ & 1.00 \\
Dark regime (1) & 0.00 & 0.00 & 0.00 & 0.30 & 0.55 & 0.85 \\
Dark regime (2) & 0.05 & 0.05 & 0.15 & 0.45 & 0.50 & 0.90 \\
Dark regime mean & $0.03^{*}$ & $0.03^{*}$ & $0.08^{*}$ & $0.38^{*}$ & $0.53^{*}$ & 0.88 \\
\hline
\end{tabular}

${ }^{a}$ At 28 days, dark regime plates were moved to the same conditions as the light regime plates.

${ }^{\mathrm{b}}$ Numbers within columns followed by an asterisk $(*)$ are statistically different according to Tukey's test $(P<0.0001)$. fertile with our isolates and to belong to the mating type "B" group. In the "A" mating group were many additional California isolates as well as an isolate from France. These results suggest that the distributions of the two mating types may substantially overlap, and therefore the cooccurrence of both mating types and thus outcrossing may be possible in California.

Although most successful pairings required two isolates of opposite mating types, two of the tested progeny isolates, 67-80 (3) and 67-85 (5), formed perithecia with both mating types in the second repetition. It is possible that the pairing plates were contaminated in the laboratory during the study or were not derived from a single ascospore but rather a mixture of two or more ascospores, one of each mating type. Another explanation may be that these progeny are actually heterokaryons, although this is doubtful because evidence of heterokaryons was not seen among our original field isolates (Table 3) or those used by Mostert et al. (28). Although selfing was not done in this experiment, we suspect that isolate 67-80 (3) was contaminated with a lesser amount of strain "A" and isolate 67-85 (5) was contaminated with a lesser amount of strain "B".

$P$. aleophilum is reported to grow at $35^{\circ} \mathrm{C}$, whereas $P$. angustius does not (7). All interfertile isolates tested in our study grew at $35^{\circ} \mathrm{C}$, which is consistent with their identification as $P$. aleophilum. The fact that the CBS 249.95 P. angustius isolate also grew well at $35^{\circ} \mathrm{C}$ supports phylogenetic analysis and suggests this isolate does not represent $P$. angustius. Our results support the work of Dupont et al. (10) who also saw colony growth of $P$. angustius (CBS 249.95) at $35^{\circ} \mathrm{C}$ and synonymized this species with $P$. aleophilum. Furthermore, the yellow pigment produced in cultures of $P$. aleophilum (CBS 246.91 and CBS 631.94) and our isolates further suggests they are P. aleophilum.

$P$. aleophilum also appears to have a light requirement for perithecial development. Once hyphae of $P$. aleophilum isolates merged on plates, 21 to 35 days of the light regime used in this study was necessary to induce perithecium formation in this study. The fact that light is a factor could offer clues as to where these structures may reside in naturally infested vineyards. Such areas include the exposed surfaces of cordons, trunks, and spurs of grapevines. Spur surfaces and girdling wounds on trunks may be the most likely source due to their large area of exposed vascular tissue, the tissue that favors perithecium formation in vitro. Spurs come from lignified shoots that have been pruned to two to three buds during the dormant season and which will produce the following year's crop. Often, old spurs are left on the vine for numerous years, and may supply the ideal habitat for these perithecia to survive from year to year. 
Mostert et al. (28) recently placed $P$. aleophilum in the Calosphaeriales near the Diaporthales based on large subunit (LSU) analysis and established that the teleomorph of $P$. aleophilum is Togninia minima. The teleomorph formed with California isolates appears morphologically identical to the teleomorph described by Mostert et al. (28). The genus Togninia (Tul. \& C. Tul.) Berl. was described in 1863 and has ascomata immersed beneath the bark and with an elongated and beaklike apex, especially in culture. The asci are described as unitunicate, oblong with trunk-like bases and thickened apices. Ascospores are one-celled, hyaline, and allantoid to elliptical $(3,21,42)$. Analysis of LSU rDNA (20) suggested that $P$. aleophilum resides in the Sordariomycetes, which is consistent with the morphology of the perithecia and ascospores produced in our pairings and those of Mostert et al. (28). Anamorph associations for the genus are poorly understood, but have been described as intermediates between Acremonium and Phialophora, similar to Phaeoacremonium (21).

Previously, there was some confusion about the correct identity of our California Phaeoacremonium isolates. Previous studies reported that $P$. inflatipes was the most commonly isolated species in California $(34,37,38)$. However, there was concern that these isolates had been misidentified and were actually $P$. aleophilum $(10,19)$. These results confirm that our isolates are $P$. aleophilum. Furthermore, the phylogenetic tree showed that these California isolates of $P$. aleophilum are capable of producing a teleomorph with ITS sequences very similar to that of T. minima described by Mostert et al. (28). A high bootstrap value of 100 was observed for this clade containing ITS sequences of our isolates, T. minima, and CBS isolates of
P. aleophilum. Furthermore, our sequence of the CBS 249.95 P. angustius isolate also grouped in this clade. Tegli et al. (40) also observed ITS similarity of $P$. angustius and $P$. aleophilum isolates received from CBS, and many others have suggested synonymizing the two $(9,10)$. However, the fact that GenBank accession AF197974 for CBS $249.95 P$. angustius is distinct from our sequence obtained from this isolate and from $P$. aleophilum sequences leads us to believe that the CBS 249.95 isolate being issued as $P$. angustius does not represent the holotype.

After moist incubating infected grapevine trunk cross sections for 6 months, we observed numerous mature perithecia of $T$. minima on the xylem and pith tissues. It appears that both mating types of $T$. minima can occur within the same vineyard and on the same vine in California. Although naturally occurring perithecia were not seen on grapevines directly from the field, the fact that they can be induced on naturally infected wood under moist conditions suggests that outcrossing is occurring in nature.

Historically, if the teleomorph for an asexual fungus was unknown, parings among different isolates were done to determine the mating system. Although this method is time-consuming, we were able to successfully use it in our research. However, this process may be extremely difficult and even more time-consuming for other fungi. To overcome these obstacles, recent advancements have been made in the isolation and characterization of mating (MAT) genes of many heterothallic fungi $(1,2,22,43)$. All heterothallic ascomycetes have a mating type (MAT) locus that determines compatibility between opposite fungal strains. Opposite strains have alternate alleles, either MAT1-1 or MAT1-2, which are also termed idio-

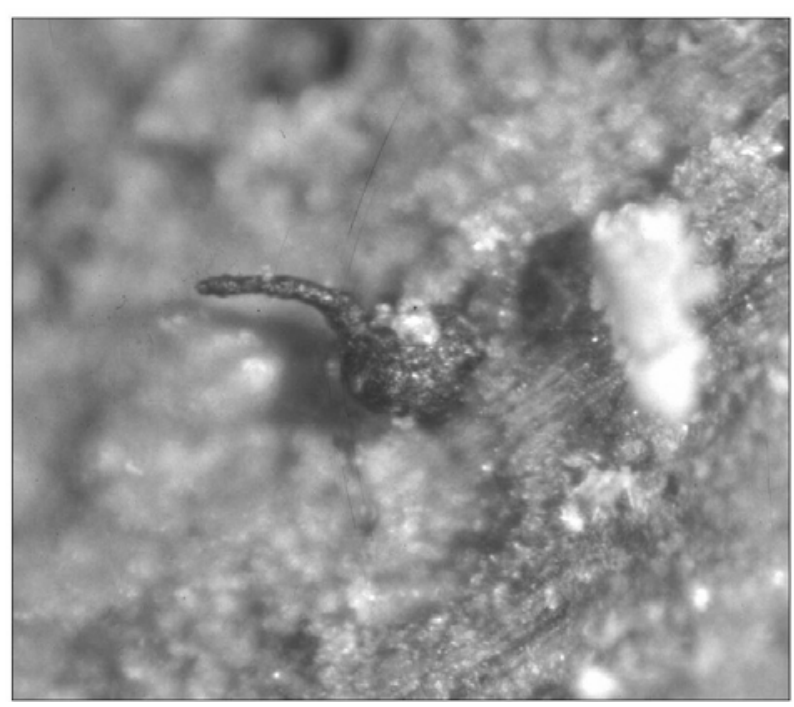

Fig. 3. Perithecium of Togninia minima developing on the xylem of a naturally infected grapevine that was moist incubated for 4 months. Numerous perithecia could be seen developing on grapevine cross sections, especially on the xylem tissue immediately surrounding the pith.

morphs. Arie et al. (1) established a PCR approach to isolate MAT genes from ascomycetes by amplifying high mobility group (HMG) proteins encoded by the MAT1-2 idiomorph. This approach was attempted in our study with opposite mating type isolates of $P$. aleophilum without success. The selected primer pairs may not have been specific for our isolates, or the thermocycler conditions were less than optimal, or both. A dependable PCR-based assay for determination of mating types would be a beneficial tool for understanding the population structure of $P$. aleophilum and the epidemiology of the diseases it causes, and we will continue to work on development of such an assay in the future.

In conclusion, temperature growth response, pigment diffusion, and molecular analyses confirm that the predominant species of Phaeoacremonium attacking grapevines in California is $P$. aleophilum. Furthermore, our results confirm that isolates from the California population of $P$. aleophilum are capable of producing a sexual stage. The fact that perithecia of $T$. minima can be induced to form on naturally infected wood by moist incubation leads us to believe that this teleomorph may be important in the disease cycle. Although not proven, ascospores might be rain dispersed, due to the watery mass of ascospores that collect on the perithecia. In addition, splash and airborne dispersal may account for the recovery of $P$. aleophilum propagules from air in proximity to diseased vines (13). This research presents significant findings on the life cycle and mating type system of this important fungal pathogen. More research is needed for a complete understanding of the disease cycle and ultimately the development of effective management strategies.

\section{LITERATURE CITED}

1. Arie, T., Christiansen, S. K., Yoder, O. C., and Turgeon, B. G. 1997. Efficient cloning of ascomycete mating type genes by PCR amplification of the conserved MAT HMG box. Fungal Genet. Biol. 21:118-130.

2. Bennett, R. S., Yun, S. H., Lee, T. Y., Turgeon, B. G., Arseniuk, E., Cunfer, B. M., and Bergstrom, G. C. 2003. Identity and conservation of mating type genes in geographically diverse isolates of Phaeosphaeria nodorum Fungal Genet. Biol. 40:25-37.

3. Berlese, A. N. 1900. Icones fungorum omnium hucusque cognitorum. Patavia 3:9-21.

4. Brown, J. K. M. 2000. Estimation of rates of recombination and migration in populations of plant pathogens. Phytopathology 90:320-323.

5. Chicau, G., Aboim-Inglez, M., Cabral, S., and Cabral, J. P. 2000. Phaeoacremonium chlamydosporum and Phaeoacremonium angustius associated with esca and grapevine decline in Vinho Verde grapevines in northwest Portugal. Phytopathol. Mediterr. 39:80-86.

6. Crous, P. W., and Gams, W. 2000. Phaeomoniella chlamydospora gen. et comb. Nov., a causal organism of Petri grapevine decline and esca. Phytopathol. Mediterr. 39:112-118.

7. Crous, P. W., Gams, W., Wingfield, M. J., and van Wyk, P. S. 1996. Phaeoacremonium gen. nov. associated with wilt and decline disease of woody host and human infection. Mycologia 
88:786-796.

8. Dupont, J., Laloui, W., Magnin, S., Larignon, P., and Roquebert, M. 2000. Phaeoacremonium viticola, a new species associated with Esca disease of grapevine in France. Mycologia 92:499-504.

9. Dupont, J., Laloui, W., and Roquebert, M. F. 1998. Partial ribosomal DNA sequences show an important divergence between Phaeoacremonium species isolated from Vitis vinifera. 1998. Mycol. Res. 102:631-637.

10. Dupont, J., Magnin, S., Cesari, C., and Gatica, M. 2002. ITS and $\beta$-tubulin markers help deliminate Phaeoacremonium species and the occurrence of $P$. parasiticum in grapevine disease in Argentina. Mycol. Res. 106:1143-1150.

11. Edwards, J., and Pascoe, I. G. 2001. In situ sporulation of Phaeomoniella chlamydospora in the vineyard. Phytopathol. Mediterr. 40:6166.

12. Edwards, J., and Pascoe, I. G. 2001. Pycnidial state of Phaeomoniella chlamydospora found on Pinot noir grapevines in the field. Australas. Plant Pathol. 30:67.

13. Eskalen, A., and Gubler, W. D. 2001. Association of spores of Phaeomoniella chlamydospora, Phaeoacremonium inflatipes and Pm. aleophilum with grapevine cordons in California. Phytopathol. Mediterr. 40:S429-432.

14. Eskalen, A., Gubler, W. D., and Khan, A. 2001. Rootstock susceptibility to Phaeomoniella chlamydospora and Phaeoacremonium spp. Phytopathol. Mediterr. 40:S433-438.

15. Eskalen, A., Rooney, S. N., and Gubler, W. D. 2002. First report of the pycnidial state of Phaeomoniella chlamydospora, a causal agent of black measles (esca) and Petri disease in California vineyards. (Abstr.) Phytopathology 92:S24.

16. Ferreira, J. H., van Wyk, P. S., and Calitz, F. J. 1999. Slow dieback of grapevine in South Africa: Stress-related predisposition of young vines for infection by Phaeoacremonium chlamydosporum. S. Afr. J. Enol. Vitic. 20:43-46.

17. Ferreira, J. H., van Wyk, P. S., and Venter, E. 1994. Slow dieback of grapevine: Association of Phialophora parasiticum with slow dieback of grapevines. S. Afr. J. Enol. Vitic. 15:9-11.

18. Gatica, M., Cesari, C., Magnin, S., and Dupont, J. 2001. Phaeoacremonium species and Phaeomoniella chlamydospora in vines showing "hoja de malvon" and young vine decline symptoms in Argentina. Phytopathol. Mediterr. 40:S317-324.

19. Groenwald, M., Kang, J., Crous, P. W., and Gams, W. 2001. ITS and $\beta$-tubulin phylogeny of Phaeoacremonium and Phaeomoniella spe- cies. Mycol. Res. 105:651-657.

20. Harrington, T. C., and McNew, D. 2003. Phylogenetic analyses place the Phialophora-like anamorph genus Cadophora in the Helotiales. Mycotaxon 87:141-151.

21. Hausner, G., Eyjolfsdottir, G., and Reid, J. 1991. Two additional species of the genus Togninia. Can. J. Bot. 70:724-734.

22. Hsiang, T., Chen, F., and Goodwin, P. H. 2003. Detection and phylogenetic analysis of mating type genes of Ophiosphaerella korrae. Can. J. Bot. 81:307-315.

23. Kang, S. C., Chumley, F. G., and Valent, B. 1994. Isolation of the mating type genes of the phytopathogenic fungus Magnaporthe grisea using genomic subtraction. Genetics 138:289296.

24. Larignon, P., and Dubos, B. 1997. Fungi associated with esca disease in grapevine. Eur. J. Plant Pathol. 103:147-157.

25. Larignon, P., and Dubos, B. 2000. Preliminary studies on the biology of Phaeoacremonium. Phytopathol. Mediterr. 39:184-189.

26. Miazzi, M., Hajjeh, H., and Faretra, F. 2003. Observations on the population of the grape powdery mildew fungus Unicinula necator. $\mathrm{J}$. Plant Pathol. 85:123-129.

27. Milgroom, M. G. 2001. The synthesis of genetics and epidemiology: Contributions of population biology in plant pathology. J. Plant Pathol. 83:57-62.

28. Mostert, L. P., Crous, P. W., Groenwald, J., Gams, W., and Summerbell, R. C. 2003. Togninia (Calosphaeriales) is confirmed as the teleomorph of Phaeoacremonium by means of morphology, sexual compatibility and DNA phylogeny. Mycologia 95:646-659.

29. Mugnai, L., Graniti, A., and Surico, G. 1999. Esca (black measles) and brown wood streaking: Two old and elusive diseases of grapevines. Plant Dis. 83:404-418.

30. Pascoe, I. 1999. Grapevine trunk diseasesblack goo decline, esca, Eutypa dieback and others. Aust. Grape Grower Winemaker 429:24-28.

31. Petri, L. 1912. Osservaziono sopra le alterazioni del legno della vite in siguito a ferrite. Le Stazioni Sperimentali Agarie Italiane 45:501547.

32. Rego, C., Oliveira, H., Carvalho, A., and Phillips, A. 2000. Involvement of Phaeoacremonium spp. and Cylindrocarpon destructans with grapevine decline in Portugal. Phytopathol. Mediterr. 39:76-79.

33. Risenzein, H., Berger, N., and Nieder, G. 2000. Esca in Austria. Phytopathol. Mediterr. 39:2634.
34. Rooney, S. N. 2002. Detection and control of Phaeomoniella chlamydospora and Phaeoacremonium spp., causal agents of Petri disease of grapevines. M.S. thesis. University of California, Davis

35. Rooney, S. N., Eskalen, A., and Gubler, W. D. 2001. Recovery of Phaeomoniella chlamydospora and Phaeoacremonium inflatipes from soil and grapevine tissues. Phytopathol Mediterr. 40:S351-356

36. Rooney, S. N., Eskalen, A., and Gubler, W. D. 2003. First report of the teleomorph of Phaeoacremonium spp., the cause of esca and decline of grapevines. (Abstr.) Phytopathology 93:S129.

37. Scheck, H. J., Vasquez, S. J., Gubler, W. D. and Fogle, D. 1998. First report of three Phaeoacremonium spp. causing young grapevine decline in California. Plant Dis. 82:590.

38. Scheck, H. S., Vasquez, S. J., Fogle, D., and Gubler, W. D. 1998. Grape growers report losses to black foot and grapevine decline. Calif. Agric. 52(4):19-23.

39. Scheck, H. S., Vasquez, S. J., Gubler, W. D., and Fogle, D. 1998. Young grapevine decline in California. Practical Winery Vineyard (May/June):32-38.

40. Tegli, S., Bertelli, E., and Surico, G. 2000. Sequence analysis of ITS ribosomal DNA in five Phaeoacremonium species and development of a PCR-based assay for the detection of $P$. chlamydosporum and $P$. aleophilum in grapevine tissue. Phytopathol. Mediterr. 39:134-149.

41. Thompson, J. D., Gibson, T. J., Plewniak, F., Jeanmougin, F., and Higgins, D. G. 1997. The Clustal X window interface: Flexible strategies for multiple sequence alignment aided by quality analysis tools. Nucleic Acids Res. 24:48764882.

42. Tulasne, L. R., and Tulasne, C. 1863. Selecta Fungorum carpologia. Paris. Vol. 2. Translated by W. B. Grove. 1931. Oxford University Press, Oxford.

43. Wallace, M. M., and Covert, S. F. 2000. Molecular mating type assay for Fusarium circinatum. Appl. Environ. Microbiol. 66:55065508.

44. White, T. J., Bruns, T., Lee, S., and Taylor, J. W. 1990. Amplification and direct sequencing of fungal ribosomal RNA genes for phylogenetics. Pages 315-322 in: PCR Protocols: A Sequencing Guide to Methods and Applications. M.A. Innis, D. H. Gefland, J. J. Sninsky, and T. J. White, eds. Academic Press, San Diego, CA. 